\title{
PENGGUNAAN LEARNING MANAGEMENT SYSTEM (LMS) UNTUK PEMBELAJARAN DIMASA PANDEMI
}

\section{Muhammad Einggi Gusti Pratama,Wahyu Andhyka Kusuma}

Universitas Muhammadiyah Malang (UMM) Jawa Timur, Indonesia

Email: enggipratama82@webmail.umm.ac.id,wahyukusuma@umm.ac.id

\begin{tabular}{ll}
\hline INFO ARTIKEL & ABSTRAK \\
\hline Diterima & Pandemi Covid-19 melanda hampir seluruh negara yang ada di \\
25 Juli 2021 & dunia, situasi tersebut sangat tidak diharapkan terjadi. Semua \\
Direvisi & aktifitas masyarakat yang dahulu dilakukan diluar rumah \\
05 Agustus 2021 & menjadi mengalami pembatasan. Salah satu dampak yang \\
Disetujui & terjadi dari kondisi ini adalah proses pembelajaran dari semua \\
15 Agustus 2021 & pendidikan dilakukan secara daring. Kondisi tersebut \\
\hline Kata Kunci: & memunculkan permasalahan baru untuk mensinkronkan \\
learning & seluruh pembelajaran dan memerlukan sebuah sistem media \\
management system & pembelajaran online. Salah satu sistem pembelajaran yang \\
(LMS); e-learning; $;$ & diterapkan adalah Learning Management System (LMS), namun \\
Pandemi & sistem ini masih perlu dikembangkan untuk mempermudah \\
& melakukan pembelajaran secara daring. Salah satu E-Learning \\
& yang menggunakan sistem Learning Management System \\
& (LMS) adalah platform Moodle. Penelitian yang dilakukan oleh \\
& peneliti bertujuan untuk mengetahui seberapa efektif sistem \\
& Learning Management System (LMS) digunakan pada saat \\
& pandemi Covid-19 serta dapat mendeskripsikan pembelajaran \\
& yang cocok untuk diterapkan dan digunakan dalam \\
& pembelajaran jarak jauh agar para tenaga pengajar maupun \\
& mahasiswa dapat terbantu untuk memahami materi yang \\
diberikan kemudian penelitian ini juga bertujuan untuk & memaksimalkan penggunaan data internet dalam pembelajaran \\
& jarak jauh.
\end{tabular}

\section{ABSTRACT}

The Covid-19 pandemic has hit almost all countries in the world, this situation is not expected to happen. All community activities that were previously carried out outside the home have become restricted. One of the impacts of this condition is that the learning process of all education is carried out online. This condition raises new problems to synchronize all learning and requires an online learning media system. One of the learning systems implemented is the Learning Management System (LMS), but this system still needs to be developed to make it easier to do online learning. One of the E-Learning

\begin{tabular}{|c|c|}
\hline How to cite: & $\begin{array}{l}\text { Pratama, M. E. G., \& Kusuma, W. A. (2021) Penggunaan Learning Management System (LMS) } \\
\begin{array}{l}\text { Untuk } \\
\text { https://doi.org/10.46799/jsa.v2i8.288 }\end{array}\end{array}$ \\
\hline E-ISSN: & $2722-5356$ \\
\hline Published by: & Ridwan Institute \\
\hline
\end{tabular}


that uses a Learning Management System (LMS) is the Moodle platform. The research conducted by researchers aims to find out how effectively the Learning Management System (LMS) system is used during the Covid-19 pandemic and can describe learning that is suitable to be applied and used in distance Keywords: learning learning so that teaching staff and students can be helped to management system understand the material being taught. given later this research (LMS); e-learning; also aims to maximize the use of internet data in distance pandemic learning.

\section{Pendahuluan}

Saat ini dunia sedang dilanda musibah pandemi Covid-19, tidak ada yang menginginkan situasi pandemi dan tidak ada prediksi sebelumnya bahwa Covid-19 akan terjadi menjadi pandemi. Pandemi Covid-19 telah mengubah beberapa struktur sosial. Penerapan social distancing menyebabkan terjadinya pergeseran pola belajar. Pandemi Covid-19 menuntut perubahan pola pembelajaran yang selama ini dilakukan secara tatap muka, kemudian bergeser ke pembelajaran jarak jauh. Pembelajaran tatap muka sangat dipengaruhi oleh peran guru sehingga masalah mulai muncul dengan tidak adanya pendampingan langsung oleh guru. Siswa yang tidak terbiasa mandiri akan kesulitan untuk mengembangkan potensinya. Pembelajaran tidak mungkin dilakukan dikelas dikarenakan hal tersebut dapat menyebabkan penyebaran virus Covid-19 (Wiratomo \& Mulyatna, 2020). Pandemi yang berlangsung hampir satu tahun menyebabkan berbagai kendala misalnya minimnya pemahaman materi belajar, kesulitan menumbuhkan minat belajar, mengatur waktu belajar yang disebabkan orangtua pergi bekerja dan sulit memantau anaknya, orang tua tidak sabar dalam mendampingi pembelajaran anaknya, pengetahuan menggunakan gadget yang masih belum dipahami, dan akses internet yang masi terbatas (Rakhmawati et al., 2021).

Pengertian Media Pembelajaran diambil dari bentuk jamak bahasa latin yaitu "Media" yang merupakan kata medium yang secara harfiah berarti perantara atau pengantar. Pengertian Media yaitu perantara atau pengantar pesan dari pengirim kepada penerima pesan. Dalam proses belajar mengajar media yang digunakan untuk memperlancar komunikasi antara tenaga pengajar dengan para murid (Ucu et al., 2018). E-Learning sendiri merupakan kegiatan belajar asynchronous melalui suatu perangkat elektronik komputer yang dimana memperoleh bahan belajar sesuai dengan kebutuhannya dan berjutuan pada penggunaan teknologi internet untuk mengirimkan beberapa solusi yang dapat meningkatkan pengetahuan dan keterampilan (Ucu et al., 2018).

Salah satu upaya yang dapat dilakukan dalam sistem pembelajaran jarak jauh selama pandemi ini adalah dengan menggunakan internet dalam proses pembelajaran dan proses pembelajaran tatap muka bergeser menjadi e-Learning (Wiratomo \& Mulyatna, 2020). Perlu dukungan tehnologi informasi berupa laptop maupun smartphone agar pembelajaran tetap berjalan di masa pandemi tidak terelakkan (Rakhmawati et al., 2021). Berkembangnya teknologi informasi serta internet 
menyebabkan pembelajaran yang dikenal luas dengan sebutan e-learning memiliki pengertian yang lebih luas dari pada online learning. E-learning bisa berbasis computer dan bisa juga disebut computer-based learning serta berbasis online learning yaitu pembelajaran dalam jaringan atau disebut daring. Online learning dapat menggunakan jaringan internet yang disebut dengan internet-based learning serta bisa berbasis website yang biasa dikenal dengan web-based learning, keduanya menggunakan jaringan online untuk dapat saling terhubung terus menerus antara pengguna yang satu dengan pengguna yang lainnya (Rakhmawati et al., 2021).

Belajar dalam situasi pandemi Covid 19 mengubah suasana akademis. Belajar dari rumah atau pembelajaran jarak jauh diperkenalkan. Blended learning juga menjadi salah satu alternatif strategi pengajaran yang dilakukan dosen untuk mendapatkan layanan pendidikan yang berkualitas. Kertas menjadi tanpa kertas. Dosen membuat presentasi dan bahan ajar dengan menggunakan soft file, e-book, dan e-mail. Daftar kehadiran siswa menggunakan tautan formulir google, bukan kertas daftar periksa. Kegiatan belajar mengajar dalam ruang kelas tidak lagi digunakan. Rapat zoom digunakan untuk menyelesaikan aktivitas sinkron dan asinkron di Sistem Manajemen Pembelajaran (LMS) (Kodrat, 2021). Dosen sudah familiar dengan banyak aplikasi seperti rapat Zoom, Google Meeting, Google classroom. Para tenaga pengajar harus berhadapan dengan LMS sebagai respon aktif terhadap revolusi industri 4.0 atau mereka akan tertinggal (Kodrat, 2021). Walaupun begitu, tidak hanya terdapat beberapa manfaat dari pembelajaran jarak jauh namun tentunya pembelajaran secara online ini memiliki kekurangan seperti munculnya kendala pada koneksi internet, keterlibatan siswa yang kurang, konektivitas elektronik serta menciptakan interaksi yang intensif saat berada di kelas (Yustika et al., 2019).

Maka dari itu perlu adanya penelitian untuk kasus ini. Dengan diadakannya penelitian ini yang bertujuan untuk mengetahui seberapa efektif system Learning Management System (LMS) dan mengetahui platform apa yang cocok untuk digunakan pembelajaran jarak jauh pada saat pandemi. Penerapkan gagasan menyediakan informasi dan sumber daya proyek melalui $L M S$, ada sebuah platform bernama canvas yang cukup banyak digunakan di perguruan tinggi karena sifatnya yang fleksibel dan mudah untuk di operasikan (Morefield \& Fabregas Janeiro, 2020).

Pengertian lebih jelas tentang e-learning adalah kegiatan belajar asynchronous melalui suatu media elektronik komputer yang memperoleh bahan belajar dengan menyesuaikan kebutuhannya dan mengarah pada penggunaan teknologi internet agar dapat mengirimkan beberapa solusi yang dapat meningkatkan pengetahuan dan keterampilan (Ucu et al., 2018). Terminologi e-learning memiliki konsep yang cukup luas ketimbang online learning. E-learning online menjadi terkenal saat kini dalam proses kegiatan belajar yang biasa disebut dengan pembelajaran daring (Nurkolis \& Muhdi, 2020). Pembelajaran daring berlaku bagi seluruh lembaga Pendidikan sehingga mengalami perubahan. Perubahan yang dialami yaitu pada motivasi belajar siswa. Sementara motivasi belajar sangat penting bagi siswa karena hal tersebut dapat mempengaruhi hasil. Maka dari itu perlu setiap siswa wajib memiliki motivasi belajar 
dalam diri mereka. (Cahyani et al., 2020) Pemakaian media pembelajaran dalam proses belajar mengajar dapat membangkitkan keinginan dan minat yang baru, membangkitkan motivasi dan rangsangan kegiatan belajar serta membawa pengaruh psikologis terhadap siswa. Oleh sebab itu, penggunaan media pembelajaran dalam proses pembelajaran sangat penting serta dapat membantu guru agar tercapainya tujuan pendidikan, Hamalik (Putra et al., 2020). E-learning sendiri memiliki 3 fitur unggulan seperti sifat dari praktek pembelajaran, sinkronisitas, dan ada atau tidak ada pendidikan tatap muka (Hoq, 2020).

Learning Management System (LMS) merupakan istilah di dunia teknologi dan dikembangkan secara khusus agar dapat mengelola dan menfasilitasi dan menjadi media untuk proses pembelajaran jarak jauh. Sebuah aktivitas pembelajaran jarak jauh yang menggunakan $L M S$ dapat dikembangkan menjadi beberapa fitur yaitu meliputi proses pendaftaran, pembayaran, distribusi bahan pembelajaran, proses interaksi antara guru dan siswa dalam kelas online, test online yang dilakukan menggunakan perangkat komputer maupun android serta ada beberapa fungsi LMS lainnya seperti publikasi materi pembelajaran, download materi pembelajaran, pemberian tugas dan penilaian yang semuanya dilakukan secara onine (Rakhmawati et al., 2021).

\section{Metode Penelitian}

Penelitian ini dilakukan untuk memberikan gambaran mengenai penerapan $e$ learning yang diwujudkan dalam bentuk kegiatan pengabdian pada masyarakat. Kegiatan pengabdian ini dapat berupa pelatihan penggunaan e-learning, dengan pokokpokok materi antara lain: perancangan perangkat berbasis daring, pengelolaan Learning Management System (LMS), penginputan materi ajar dan penggunaan LMS dalam proses belajar mengajar. Metode penyajian materi dilakukan secara demonstratif, yaitu mendemonstrasikan dan menjelaskan cara-cara penggunaan fitur-fitur yang ada di $L M S$ dan dipraktekkan langsung oleh peserta yang membawa laptop. Selanjutnya guru diberikan tugas mandiri dalam bentuk projek yang kemudian akan diterapkan dalam mata pelajaran yang menjadi tanggung jawab mereka di sekolah (dyah darma Andayani et al., 2020). Penelitian ini melalui beberapa tahapan, yang pertama yaitu tahapan evaluasi awal yang dilakukan untuk mengetahui kondisi awal dan kemampuan dasar serta kebutuhan masing-masing peserta. Kemudian tahap evaluasi proses dilakukan pada saat pelatihan berlangsung untuk mengetahui sejauh mana pelaksanaan kegiatan dapat diikuti oleh peserta. Yang terakhir tahap evaluasi akhir dilakukan di tahap akhir pelaksanaan kegiatan untuk mengetahui sejauh mana efektifitas pelaksanaan kegiatan, bagaimana tingkat keberhasilan pelatihan yang diperoleh, serta tingkat penguasaan keterampilan peserta pelatihan. Semua tahapan itu dilakukan secara daring mengingat kondisi saat ini masih diberlakukannya protokol kesehatan (dyah darma Andayani et al., 2020).

Kemudian metode lain yang dilakukan meliputi kegiatan yang menggunakan online service learning. Pendekatan online service learning dilakukan untuk mendampingi para pengajar supaya dapat belajar bersama dalam simulasi proses belajar 
mengajar dengan menggunakan kelas virtual (online), yang dilakukan dalam 3 tahap, yakni tahap persiapan, tahap melayani, dan tahap refleksi (Wajdi et al., 2020). Setelah itu metode yang digunakan untuk Learning Management System (LMS) menggunakan model pengembangan ADDIE. Model inidipilih karena, desain pengembangannya sederhana dan sistematis (Rakhmawati et al., 2021). Model ADDIE merupakan model pengembangan yang terdiri dari 5 tahap yaitu: Analysis, Design, Develop, Implement, Evaluate (evaluasi). Pada tahap analysis (analisis) terdiri dari dua kegiatan yaitu analisis kebutuhan dan analisis komponen perangkat learning management system (LMS). Tahap design (perancangan) dimulai dari merencanakan perangkat learning management system (LMS) yang mudah digunakan, menyusun menu tampilan dalam perangkat LMS, menyusun rincian menu pada masing-masing tampilan, menentukan tema, merencanakan pembelajaran, mengembangkan sumber belajar, merancang ruang untuk melakukan pembelajaran sinkronus (web meeting) serta merancang tampilan untuk mengupload tugas. Tahap terakhir pada tahap pengembangan dilakukan pengisian pada menu di masing-masing tampilan, memasukkan rencana pembelajaran daring pada $L M S$, mengunggah sumber belajar daring yang digunakan, menyediakan ruang untuk melakukan pembelajaran sinkronus (web meeting). Metode tersebut menggunakan pengumpulan data melalui observasi, survey dan wawancara (Rakhmawati et al., 2021).

Penelitian yang dilakukan menggunakan pendekatan user persona. Alur yang dilalui seperti yang ditunjukkan pada gambar. User persona adalah teknik yang digunakan untuk mengetahui aspek apa yang dibutuhkan oleh pengguna. Dimana responden yang diwawancarai ada beberapa stakeholder, antara lain: dosen, mahasiswa, dan admin.

\section{Hasil dan Pembahasan}

Seluruh negara sedang menghadapi virus Covid-19, yang telah membunuh ribuan orang di seluruh dunia, proses belajar mengajar juga dilakukan secara daring dengan menggunakan e-learning untuk menekan penyebaran virus. Tetap berada di rumah adalah salah satu langkah untuk mengurangi penyebaran Covid-19, dan teknologi adalah bagian penting dari kehidupan kita sehari-hari. E-learning, Internet, computer dan smartphone telah digunakan secara vital dalam proses belajar mengajar (Arshad et al., 2020). E-learning dapat membawa suasana baru dalam ragam pengembangan pembelajaran. Pemanfaatan e-learning dengan baik dapat meningkatkan hasil pembelajaran dengan maksimal (Lilis et al., 2020).

Penelitian ini hasilnya mencakup ruang bagi guru untuk menilai dengan tepat metode mana yang cocok untuk meningkatkan keberhasilan siswa dalam mencapai hasil pembelajaran yang mereka harapkan dengan menggunakan sumber daya utama Learning Management System (LMS) termasuk berbagi video pelajaran, presentasi, PPT, dll, serta evaluasi elektronik, kuis, dan tugas (Arshad et al., 2020).

Tahap awal peneliti akan menjelaskan secara detail mengenai latar belakang dan urgensi dalam penelitian ini setelah penjelasan tersebut selesai tim pengembang akan melakukan wawancara dengan para akademisi (Setiawan et al., 2021). Tujuan kegiatan 
ini agar mendapatkan kesepahaman dan kesepakatan sebelum melaksanakan validasi dan uji coba. Berdasarkan hasil wawancara yang dilakukan kepada para akademisi mendapatkan hasil dan masukan sebagai berikut : (1) akses untuk login di LMS agar dapat dipermudah untuk dapat diakses setidaknya menggunakan android, (2) guru dan orang tua yang dalam hal ini sebagai pengguna LMS harus diberikan pemahaman agar dapat menggunakan LMS secara mandiri, (3) tampilan LMS perlu dibuat lebih menarik agar lebih cocok untuk sasaran penelitian yaitu anak usia 4-6 tahun, (4) aplikasi ini bagus dan dapat membantu guru untuk mengadministrasikan program-program sekolah (Rakhmawati et al., 2021).

Tahapan desain atau perancangan para tim pengembang akan merencanakan $L M S$ yang kemudian di terapkan dengan fitur-fitur sebagai berikut; (1) Perencanaan kegiatan pembelajaran, fitur ini teredia agar para tenaga pengajar dapat mempersiapkan bahan pembelajaran dan merancang kegiatan pembelajaran secara daring. Fitur ini juga dapat berfungsi untuk mengorganisasikan seluruh perencanaan, bahan pembelajaran yang digunakan serta pelaksanaan kegiatan pembelajaran dapat dilakukan secara tersistem, (2) Kegiatan pembelajaran secara sinkronus, dalam fitur ini tersedia agar para tenaga pengajar dapat menyapa dan melaksanakan kegiatan pembelajaran secara daring atau online menggunakan platform google meet yang langsung ditautkan dalam LMS, (3) Fitur unggah tugas siswa, fitur ini disediakan agar memudahkan mahasiswa untuk mengumpulkan tugas yang telah diselesaikan, fitur ini juga sangat membantu dalam mengorganisasikan dan menilai seluruh hasil yang sudah dikerjakan, (4) Jurnal atau history pembelajaran, fitur ini disediakan agar dapat mencatat seluruh aktivitas yang telah dilakukan pada hari itu yang dimana hasil dari jurnal pembejaran dapat dijadikan acuan/perbaikan untuk pelaksanaan pembelajaran selanjutnya (Rakhmawati et al., 2021).

\section{Menentukan Stakeholder}

Stakeholder 1 Dosen

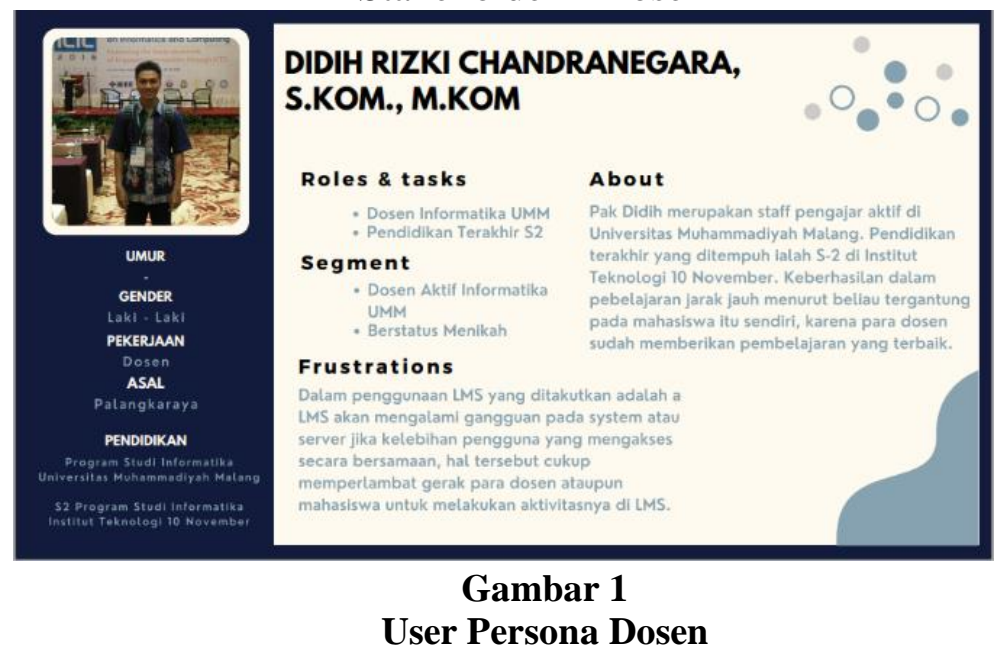

2. Tabel

Data penggunaan Learning Management System (LMS) sebelum adanya pandemi Covid-19 terdapat pada tabel 1 dibawah ini yang diambil dari LMS platform 
Sinta Indonesia pada tahun 2010 sampai 2019. Dalam data tersebut terlihat bahwa platform Moodle paling banyak digunakan, sementara itu Classdojo, Brightspace dan Microsoft Teams tidak pernah digunakan. Itu semua dikarenakan kurang adanya sosialisasi, dan iklan pada platform tersebut agar masyarakat familiar dan sebaliknya, Moodle sangat banyak digunakan di indonesia (Setiawan et al., 2021).

Tabel 1

Sebelum Pandemi Covid-19

\begin{tabular}{ccc}
\hline No & Platform & Quantity \\
\hline 1 & Moodle & 67 \\
\hline 2 & Edmodo & 31 \\
\hline 3 & Classdojo & 0 \\
\hline 4 & Schoology & 14 \\
\hline 5 & Brightspace & 0 \\
\hline 6 & Google Classroom & 14 \\
\hline 7 & Microsoft Teams & 0 \\
\hline & Total & 126 \\
\hline
\end{tabular}

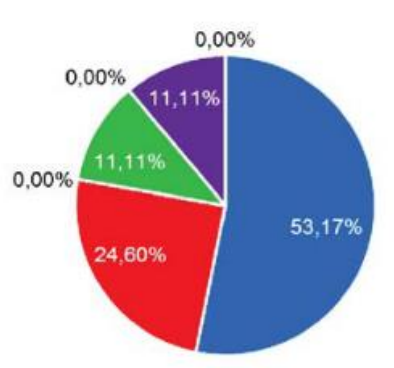

LMS Type

- Moodle

- Edmodo

Classdojo

- Schoology

- Brightspace

- Google Classroom

- Microsoft Teams

Gambar 2

Sebelum pandemic Covid-19

Kemudian data penggunaan Learning Management System (LMS) pada tahun 2020 disaat pandemi Covid-19 masih ada terlihat pada tabel 2. Hasilnya terlihat bahwa jumlah $L M S$ yang digunakan turun drastis dari tahun sebelumnya, namun data ini belum valid dikarenakan pandemi terjadi pada bulan maret 2020 sedangkan data yang dikeluarkan data pada bulan januari 2020. tetapi berdasarkan kuesioner yang di sebarkan presentasi penggunaan $1 \mathrm{~ms}$ bisa dilihat pada gambar 2 dibawah ini. Terlihat bahwa grafik menunjukan peningkatan penggunaan google classroom sebagai salah satu media pembelajaran jarak jauh (Setiawan et al., 2021).

Tabel 2

Sesudah Pandemi

\begin{tabular}{ccc}
\hline No & Platform & Quantity \\
\hline 1 & Moodle & 1 \\
\hline 2 & Edmodo & 0 \\
\hline 3 & Classdojo & 0 \\
\hline 4 & Schoology & 2 \\
\hline 5 & Brightspace & 0 \\
\hline
\end{tabular}




\begin{tabular}{ccc}
\hline 6 & Google Classroom & 0 \\
\hline 7 & Microsoft Teams & 0 \\
\hline & Total & 3 \\
\hline
\end{tabular}

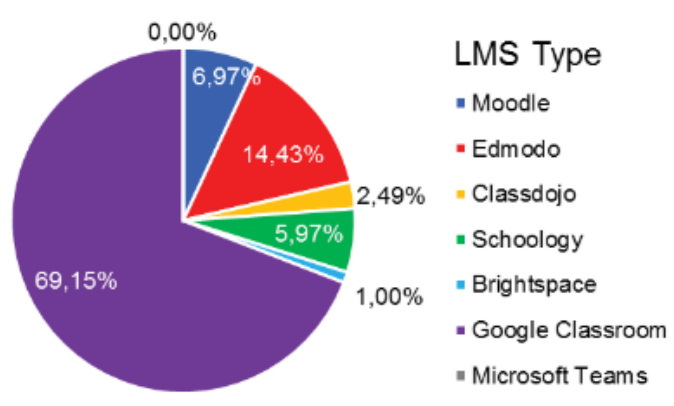

Gambar 3

Sesudah pandemic Covid-19

\section{Kesimpulan}

Kesimpulan dari penelitian ini adalah pembelajaran jarak jauh sangat bergantung pada koneksi internet dan alat-alat pendukung lainnya seperti laptop maupun smartphone. Kemudian untuk Learning Management System (LMS) masih perlu banyak perkembangan guna menyempurnakan fitur-fitur yang telah ada maupun memunculkan fitur-fitur baru, tidak hanya itu untuk memahami sistem yang sebelumnya tidak pernah atau jarang di pakai butuh waktu untuk belajar bisa mengoperasikan sistem LMS oleh karna itu penelitian ini kami harapkan bisa sedikit membantu para tenaga pengajar maupun siswa dan mahasiswa untuk memahami sistem E-Learning ini. Keterbatasan penelitian ini adalah pada saat melakukan pengambilan data terkendala pada sinyal yang tidak stabil mengingat semua pengumpulan data dilakukan dengan cara daring dan tidak semua responden memiliki sinyal yang bagus di daerah mereka. 


\section{BIBLIOGRAFI}

Arshad, M., Almufarreh, A., Noaman, K. M. G., \& Saeed, M. N. (2020). Academic Semester Activities by Learning Management System during Covid-19 Pandemic: A Case of Jazan University. International Journal on Emerging Technologies, 11 (5), 213-219. www.researchtrend.net. Google Scholar

Cahyani, A., Listiana, I. D., \& Larasati, S. P. D. (2020). Motivasi Belajar Siswa SMA pada Pembelajaran Daring di Masa Pandemi Covid-19. IQ (Ilmu Al-Qur'an): Jurnal Pendidikan Islam, 3 (01), 123-140. https://doi.org/10.37542/iq.v3i01.57. Google Scholar

Dyah darma Andayani, Fathahillah, \& nurul mukhlisah Abdal. (2020). Penerapan ELearning Sebagai Alternatif Pembelajaran. Peluang Dan Tantangan Pengabdian Kepada Masyarakat Yang Inovatif Di Era Kebiasaan Baru, 228-236. Google Scholar

Hoq, M. Z. (2020). E-Learning During the Period of Pandemic (Covid-19) in the Kingdom of Saudi Arabia: An Empirical Study. American Journal of Educational Research, 8 (7), 457-464. https://doi.org/10.12691/education-8-7-2. Google Scholar

Kodrat, D. (2021). Management of The Main Course Learning Management System (LMS) By Lecturers In Promoting A Quality Class. UICELL Conference Proceeding, 5 (December), 114-120. Google Scholar

Lilis, A., Ulfah, S. I., \& Endang, D. R. (2020). The Effectiveness of Using E-Learning as Learning Media. JKBM (Jurnal Konsep Bisnis Dan Manajemen), 7 (November), 72-81. https://doi.org/10.31289/jkbm.v7i1.4333. Google Scholar

Morefield, S., \& Fabregas Janeiro, M. G. (2020). Using Learning Management Systems to Provide 4-H Programming During the COVID-19 Pandemic and Beyond. Journal of Extension, 58 (6), 1-5. Google Scholar

Nurkolis, N., \& Muhdi, M. (2020). Keefektivan Kebijakan E-Learning berbasis Sosial Media pada Paud di Masa Pandemi Covid-19. Jurnal Obsesi : Jurnal Pendidikan Anak Usia Dini, 5 (1), 212. https://doi.org/10.31004/obsesi.v5i1.535. Google Scholar

Putra, E. A., Sudiana, R., \& Pamungkas, A. S. (2020). Pengembangan Smartphone Learning Management System (S-LMS) Sebagai Media Pembelajaran Matematika di SMA. Kreano, Jurnal Matematika Kreatif-Inovatif, 11 (1), 36-45. https://doi.org/10.15294/kreano.v11i1.21014. Google Scholar

Rakhmawati, N. I. S., Mardliyah, S., Fitri, R., Darni, D., \& Laksono, K. (2021). Pengembangan Learning Management System (LMS) di Era Pandemi Covid-19 pada Pendidikan Anak Usia Dini. Jurnal Obsesi : Jurnal Pendidikan Anak Usia Dini, 6 (1), 107-118. https://doi.org/10.31004/obsesi.v6i1.991. Google Scholar 
Setiawan, A. M., Munzil, \& Fitriyah, I. J. (2021). Trend of learning management system (LMS) platforms for science education before-after Covid-19 pandemic. AIP Conference Proceedings, 2330 (March), 5-10. https://doi.org/10.1063/5.0043196. Google Scholar

Ucu, N. L., Paturusi, S. D. E., \& Sompie, S. R. U. A. (2018). Analisa Pemanfaatan ELearning Untuk Proses Pembelajaran. Jurnal Teknik Informatika, 13 (1). https://doi.org/10.35793/jti.13.1.2018.20196. Google Scholar

Wajdi, M. B. N., Ubaidillah, M. B., Mulyani, S., Anwar, K., Istiqomah, L., Rahmawati, F., Hikmawati, S. A., Ningsih, D. R., \& Rizal, H. S. (2020). Pendampingan Redesign Pembelajaran Masa Pandemi Covid-19 bagi Tenaga Pendidik di Lembaga Pendidikan berbasis Pesantren di Jawa Timur. Engagement: Jurnal Pengabdian Kepada Masyarakat, 4 (1), 266-277.

https://doi.org/10.29062/engagement.v4i1.193. Google Scholar

Wiratomo, Y., \& Mulyatna, F. (2020). Use of Learning Management Systems in Learning Efforts during a Pandemic. Journal of Mathematical Pedagogy (JoMP), 1 (2), 62-71. Google Scholar

Yustika, G. P., Subagyo, A., \& Iswati, S. (2019). Masalah Yang Dihadapi Dunia Pendidikan Dengan Tutorial Online: Sebuah Short Review. Tadbir: Jurnal Studi Manajemen Pendidikan, 3 (2), 187. https://doi.org/10.29240/jsmp.v3i2.1178. Google Scholar

\section{Copyright holder:}

Muhammad Einggi Gusti Pratama,Wahyu Andhyka Kusuma (2021)

First publication right:

Jurnal Syntax Admiration

This article is licensed under:

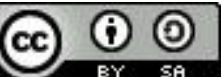

